\title{
Plaučių navikụ ilgosios ašies ir tūrių pokyčio palyginimas vertinant atsaką i gydymą
}

\author{
COMPARISON OF LINEAR MEASUREMENTS AND VOLUME CHANGES \\ IN RESPONSE TO TREATMENT OF LUNG CANCER
}

\author{
ANDRIUS STRAZDAS ${ }^{1}$, IGNĖ URBONAVIČIŪTE் ${ }^{2}$, JURGITA ZAVECKIENE் ${ }^{1}$ \\ ${ }^{1}$ LSMU MA Radiologijos klinika, ${ }^{2}$ LSMU MA Medicinos fakultetas
}

\begin{abstract}
Santrauka. Plečiantis plaučių vėžio (PV) gydymo metodams ir galimybėms, kasdienejje klinikinejje praktikoje vis dažniau susiduriama su taikomų naviko atsako ị gydymą vertinimo metodikų ribotumo ir tobulinimo klausimais. Standartizuota solidinių navikų atsako vertinimo metodika RECIST (angl. Response Evaluation Criteria in Solid Tumours) 1.1 ne visais atvejais gali užtikrinti ankstyvą progresuojančios ligos nustatymą. Tyrimo tikslas. Išanalizuoti išmatuojamų navikų matmenų ir tūrių pokyčių skirtumus, vertinant PV atsaką ị gydymą kompiuterinės tomografijos (KT) vaizduose. Tyrimo metodai. Retrospektyviai ịvertinti 2016-2019 m. ịprastai atliktų KT tyrimų duomenys. Atrankos kriterijai: verifikuotas nesmulkių ląstelių PV, KT tyrimas atliktas prieš gydymą ir du KT tyrimai gydant; plaučiuose nustatytas bent vienas išmatuojamas navikinis darinys. Matuotas navikinio darinio ilgosios ašies matmuo (IA) ir tūris pagal elipsès (VT) ir sferos modelius (VS). Matavimai atlikti rankiniu ir pusiau automatiniu būdu, naudojant VitreaWorkstation ${ }^{\text {nu }}$ CAD programinę įrangą. Dydžių pokyčiai vertinti remiantis RECIST 1.1 kategorijomis: progresuojanti liga (PL), dalinis atsakas ir stabili liga. Rezultatai. Tyrime analizuoti 125 pacientų duomenys. Išmatuoti 145 navikiniai dariniai ir ịvertintas jų atsakas ị gydymą. Nustatytas labai stiprus ryšys tarp IA ir VT prieš gydymą ir gydant (atitinkamai r=0,921, I r=0,937, II r=0,920). Vertinant VT pokyčius I ir II kontrolinių tyrimų vaizduose, PL nustatyta dažniau nei vertinant IA pokyčius, atitinkamai - 13,8 proc. ir 6,9 proc. Remiantis VT padidejimu, I kontroliniame tyrime nustatytas PL dažnis 36,6 proc. ( $n=53)$ atitiko IA II kontroliniame tyrime nustatytą PL dažnį 35,9 proc. ( $n=52)$. Išvada. Nustatytas labai stiprus ryšys tarp naviko IA ir VT. Naviko VT padidejimas gali būti jautresnis būdas ịvertinti PL PV sergantiems pacientams. Reikšminiai žodžiai: RECIST 1.1, tikrasis naviko tūris, kompiuterinè tomografija, plaučių vėžys.

Summary. The rapid improvements of lung cancer (LC) therapy are ahead of limited methods used in daily practice to evaluate the response to treatment. Standardized RECIST (Response Evaluation Criteria in Solid Tumors) 1.1 approach towards solid tumor response evaluation cannot ensure the detection of early disease progression in some cases. The aim of this study was to analyze the differences between linear measurements and volume changes of measurable tumors in computed tomography (CT) images in response to treatment of LC. Methods. CT scans performed between 2016 and 2019 were analyzed retrospectively. Selection criteria included: verified non-small cells LC (NSCLC); availability of one pre-treatment and two CT scans during treatment; at least one measurable lung tumor. Linear measurement (LM) and volume (V) by an ellipse (VE) and spherical (VS) models of tumor were measured. Manual and semi-automated measurements (VitreaWorkstation ${ }^{\text {nt }}$ CAD software) were performed. Size alterations were assessed according to RECIST 1.1: progressive disease (PD), partial response (PR) and stable disease (SD). Results. 125 cases were analyzed. 145 tumors were measured and response to treatment was evaluated. A very strong correlation between LM and VE was found before and during treatment (respectively r=0.921, I r=0.937, II $r=0.920$ ). PD was found more often evaluating VE changes in I and II control scans compared to LM changes, respectively $13.79 \%$ and 6.9\%. Assessing an increase of VE in I control scan, PD frequency was 36.6\% $(n=53)$ accordingly matched with PD frequency $35.9 \%(n=52)$ detected in II control scan. Conclusion. A very strong correlation between LM and VE was found. An increase in tumor VE could be more sensitive when evaluating lung cancer progression.
\end{abstract}

Keywords: RECIST 1.1, real tumor volume, computed tomography, lung cancer.

\section{IVADAS}

Plaučių vėžys (PV) yra dažniausia mirčių nuo vèžio priežastis pasaulyje [1]. Per pastaruosius kelis dešimtmečius PV gydymo galimybès labai išsiplètè. Taikoma ne tik chirurginis, spindulinis bei ilgą laiką pasirinkimo metodu buvusi chemoterapija, tačiau atsirado taikinių ir biologinè terapija, kuri prailgina pacientų išgyvenamumą [2-4]. Nuo 2009 m. PV atsako i gydymą vertinimui klinikinejje praktikoje vis dažniau naudojama standartizuota atsako vertinimo kriterijų sistema RECIST 1.1 (angl. Response Evaluation Criteria in Solid Tumors) $[5,6]$. Tačiau, atsirandant naujoms galimybėms, susiduriama su RECIST 1.1 ribotumais klinikineje praktikoje. Taikant biologinę terapiją, gy- 


\section{Moksliniai darbai ir apžvalgos}

dant tirozinkinazių inhibitoriais (TKI), angiogenezę slopinamaisiais vaistais arba imunoterapija, darinys gali padidèti dèl gero atsako sukeltų intranavikinių hemoragijų, nekrozès, edemos arba infiltracijos imuninèmis ląstelèmis, o PL gali būti nustatoma klaidingai [7-9]. Nustačius PL pagal RECIST 1.1, kartais gydymas TKI neturètų būti nutraukiamas, kadangi navikinès ląstelès auga lètai ir išlieka jautrios TKI [10]. RECIST 1.1 kiekybiškai neapibrèžia nereikšmingo netaikininių darinių didejjimo, todèl nuostata, jog toks pokytis nereikšmingas PL identifikavimui [7], leidžia daryti prielaidą, kad taikinių didejimui, nesiekiant ribinio dydžio ir neatsiradus naujų darinių, stabilios ligos (SL) kategorinis vertinimas gali kelti abejonių ir yra diskutuotinas. Taikant imunoterapiją, dažnai nustatomas pseudoprogresas, todèl šiais atvejais taikant RECIST 1.1 PL gali būti nustatoma klaidingai [7-9].

Gydant angiogenezę slopinamaisiais vaistais, dažnai nustatomas naviku irimas [10, 11], tačiau RECIST 1.1 neįvertina ertminio komponento reikšmès, todèl kategorinis atsako vertinimas gali būti klaidingas. Kitas RECIST 1.1 sistemos ribotumas yra matavimų skirtumai tarp tyrèjų [7]. Dinkel J. ir bendraautoriai nustatė, jog taikant pusiau automatinị naviko tūrio matavimą, nuo tyrejo priklausomas rezultatų kintamumas, lyginant su linijiniais matavimais, gali būti sumažinamas nuo trečdalio iki pusès atvejų [12]. Nishino M. ir kiti įrodè dar vieną RECIST 1.1 sistemos naudojimo ribotumą, kai išmatuojamas naviko IA ašies padidejimas yra minimalus, tačiau ịvertinus tūrius, nustatomas reikšmingas dydžio pokytis [10].

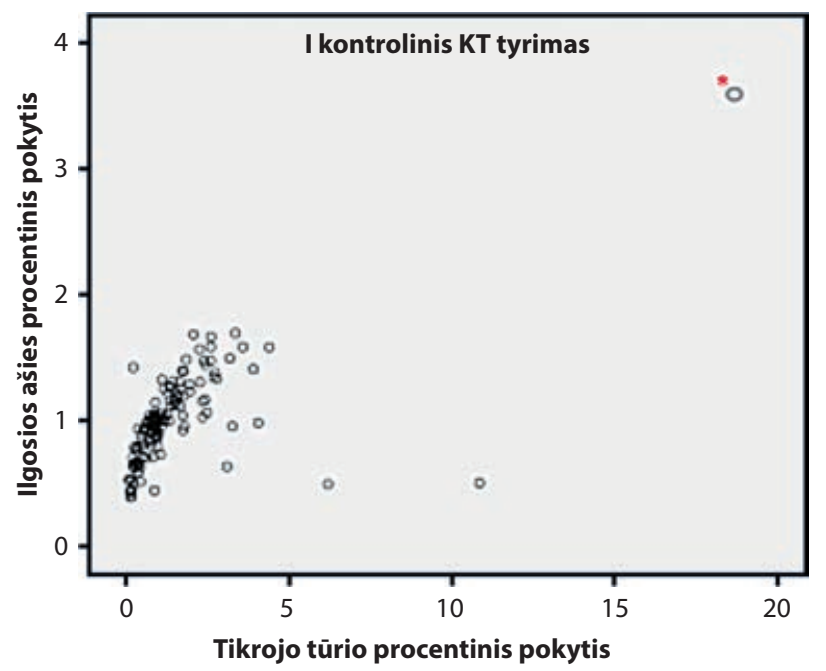

Siekiant optimizuoti PV gydymą, sumažinti vẻlyvosios PL diagnostikos tikimybę bei didinti racionalų resursų naudojimą, ieškoma papildomų objektyvaus atsako radiologinio ịvertinimo būdų ir metodikų.

\section{TYRIMO METODIKA}

Retrospektyviai vertinti pacientų, 2016-2019 m. tirtų ir gydytų Kauno klinikose, itprastai pagal standartizuotą protokolą Toshiba Aquilion One 320 pjūvių kompiuterinès tomografijos (KT) aparatu atliktų krūtinès KT tyrimų duomenys. Atrankos kriterijai: verifikuotas NSLPV, gydytas chemoterapija, taikinių ir biologine terapija, KT vaizduose plaučiuose nustatytas bent vienas, bet ne daugiau nei du išmatuojami navikiniai dariniai.

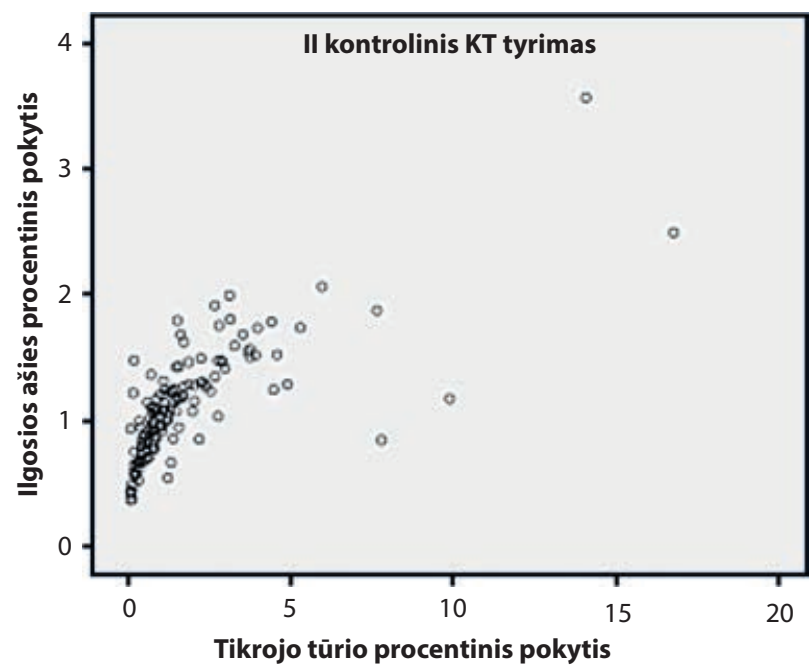

1 pav. Navikinio darinio ilgosios ašies ir tikrojo tūrio pokyčių koreliacija

Santrumpos: KT - kompiuterinè tomografija.

* - kritinè reikšmè $(x=53 ; y=4,43)$. 


\section{Moksliniai darbai ir apžvalgos}

Pagal RECIST 1.1 reikalavimus, bazinis KT tyrimas buvo atliktas praejus $\leq 28$ dienoms iki gydymo pradžios bei vertinti du pirmieji KT tyrimai pradejus gydymą (I ir II). Atmetimo kriterijai: kontroliniuose tyrimuose išryškejjo plaučių infiltracija, dalinè/visiška atelektazè arba kita būklè, neleidžianti tiksliai išmatuoti navikinio darinio, pasiektas visiškas atsakas. Ivvertinti 145 išmatuojami navikiniai dariniai plaučiuose. Matuotas darinio ilgosios ašies matmuo (IA) ir naviko tūris (V) pagal elipsès (tikrasis) (VT) ir sferos modelius (VS). Matavimai atlikti rankiniu ir pusiau automatiniu būdu rekonstrukciniuose $1,25 \mathrm{~mm}$ storio pjūvių vaizduose vieno gydytojo radiologo. VT išmatuotas naudojant VitreaWorkstation ${ }^{\text {тм }}$ CAD programinę įrangą, taikant rankinę korekciją (iškerpant kraujagysles, ertmes, pažymint ribą nuo gretimų struktūrų). Dydžių pokyčiai vertinti grupèse remiantis RECIST 1.1 kategorijomis - PL, dalinis atsakas (DA), stabili liga (SL) (1 lentelè).

Vertintas kiekvieno matuoto darinio atsakas. Nematuojami dariniai tyrime nevertinti.

Kauno regioninio Biomedicininių tyrimų Etikos komiteto leidimas Nr. BE-2-6 buvo išduotas 2019-02-07. Statistinè duomenu analizè atlikta naudojant SPSS 25.0 statistinès analizès paketą. Grupių homogeniškumas vertintas naudojant neparametrini chi kvadrato $\left(\chi^{2}\right)$ požymių nepriklausomumo kriterijų. Dviem nepriklausomoms imtims palyginti naudotas Mann-Whitney U testas. Koreliacijai vertinti pasirinktas neparametrinis Spearmano koreliacijos koeficientas. Pasirinktas reikšmingumo lygmuo $\mathrm{p} \leq 0,05$.

\section{REZULTATAI}

Atlikta 2411 pacientų îprastų KT tyrimų vaizdų retrospektyvioji analizè, kriterijus atitiko 125 pacientu atvejai. Atrinkti ir įvertinti 145 plaučių navikiniai dariniai. Tiriamosios grupès pacientų amžiaus vidurkis buvo $65,7 \pm 11,01$ m., vyrai sudare 78 proc., moterys 28 proc. Navikinių darinių dydžiai pateikti 2 lentelèje.

Visuose trijuose KT tyrimuose nustatyti IA dydžių skirtumai tarp vertintojo matavimų ir VitreaWorkstation $^{\mathrm{TM}} \mathrm{CAD}$ sistemos buvo nereikšmingi (atitinkamai: $\mathrm{p}=0,579$, I $\mathrm{p}=0,141$ ir II $\mathrm{p}=0,389$ ).

Nustatyta labai stipri koreliacija tarp IA ir VT prieš gydymą ir gydant (I ir II), atitinkamai: $r=0,921$, $\mathrm{r}=0,937, \mathrm{r}=0,920(\mathrm{p}<0,01)$.

Vertinant IA ir VT pokyti, nustatyta stipri koreliacija gydant (I ir II): $r=0,755$ ir $r=0,815$, ( $p<0,01$ ) (1 pav.).

Po II kontrolinio KT tyrimo nustatyta, kad IA ir VT neatitikimas, kai nustatoma PL, statistiškai reikšmingai mažèja didejjant tiriamojo amžiui $(r=-0,278, p=0,029)$.

Vertinant naviko tūrio pokyčius I ir II kontrolinių tyrimų vaizduose, PL ir DA nustatyti dažniau nei vertinant IA, atitinkamai: 13,8 proc. ir 6,7 proc. bei 15,2 proc. ir 18,6 proc. Pagal VT padidejimą I tyrime nustatyta PL 36,6 proc. $(n=53)$ atitiko pagal IA II tyrime nustatytą PL 35,9 proc. $(\mathrm{n}=52)$ (3 lentelè).

Vertinant VS pokyčius, SL nustatyta dažniau, o PL nustatyta rečiau nei vertinant IA pokyčius po II kontrolinio tyrimo, atitinkamai 7,6 proc. ir 8,3 proc.

Po abiejų kontrolinių tyrimų (I ir II) nustatyti statistiškai reikšmingi IA ir VT pokyčiai visose grupèse: SL, DA, PL $(p<0,05)$. Vertinant IA ir VS pokyčius, statistiškai reikšmingas skirtumas nustatytas tik PL grupèje po II kontrolinio tyrimo $(\mathrm{p}<0,05)$.

Gydant VT ir VS pokytis skyrèsi statistiškai reikšmingai $(\mathrm{p}<0,05)$ : didžiausias skirtumas nustatytas SL grupèje, o DA ir PL grupèse skirtumas buvo panašus (2 pav.).

\section{REZULTATŲ APTARIMAS}

Šiuo metu klinikinèje praktikoje vertinant navikų atsaką ì gydymą dažniausiai naudojama RECIST 1.1 


\section{Moksliniai darbai ir apžvalgos}
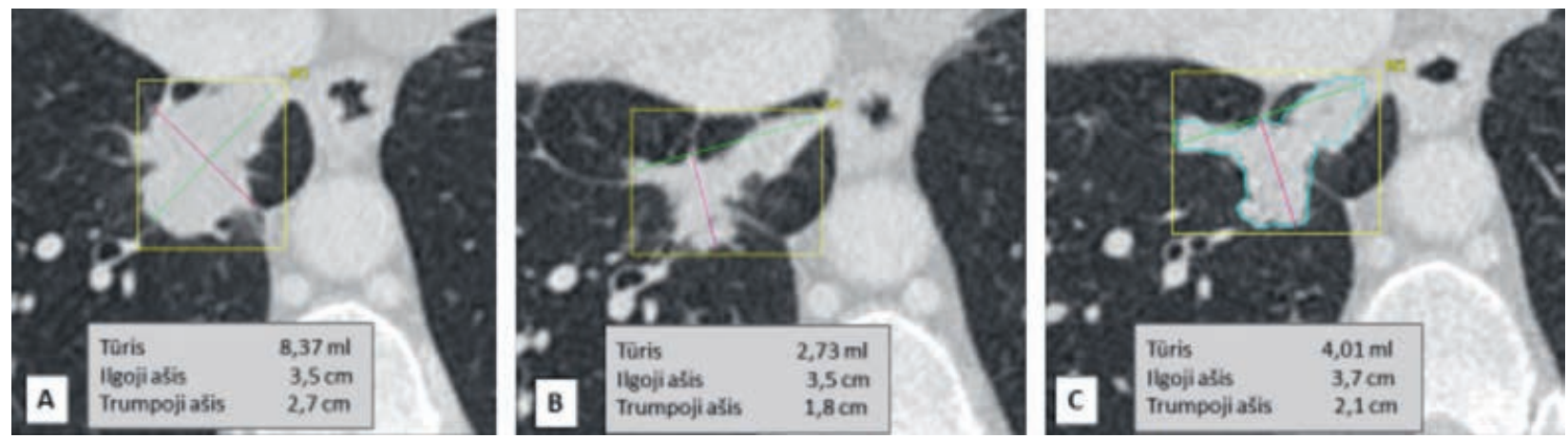

3 pav. (A) - KT tyrimas prieš gydymą; (B) - po I kontrolinio KT tyrimo; (C) - po II kontrolinio KT tyrimo; pagal RECIST 1.1 po abiejų kontrolinių tyrimų nustatyta SL; pagal VT - po I kontrolinio KT tyrimo gautas DA, po II - PL

Santrumpos: DA - dalinis atsakas; KT - kompiuterinè tomografija; PL - progresuojanti liga; SL - stabili liga; VT - tikrasis tūris.
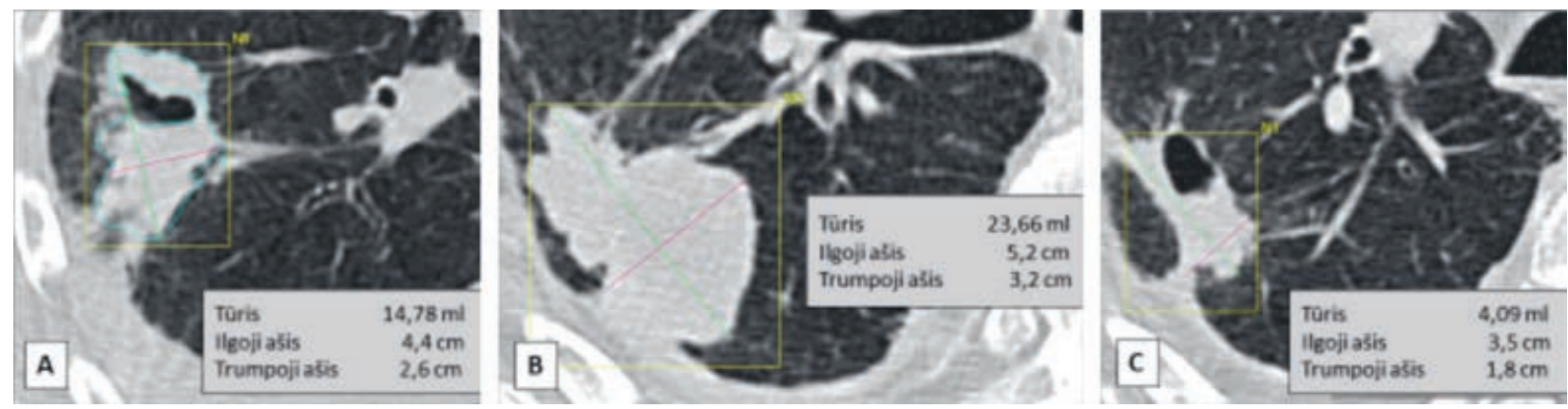

4 pav. (A) - KT tyrimas prieš gydymą; (B) - po I kontrolinio KT tyrimo; (C) - po Il kontrolinio KT tyrimo; pagal RECIST 1.1 po abiejų kontrolinių tyrimų nustatyta SL; pagal VT - po I kontrolinio KT tyrimo gauta PL, po II - DA

Santrumpos: DA - dalinis atsakas; KT - kompiuterinè tomografija; PL - progresuojanti liga; SL - stabili liga; VT - tikrasis tūris.

sistema. Plečiantis PV gydymo galimybėms tikslus atsako įvertinimas ir ankstyvas PL nustatymas yra ypač svarbus ir sąlygoja savalaikę gydymo taktikos korekciją. Tai gali padèti išvengti ne tik tolesnio ligos progresavimo, bet ir šalutinių poveikių, susijusių su neveiksmingu gydymu. Pristatant RECIST 1.1 sistemą, darbo grupe teigè, kad taikinio didžiausio matmens pokytis nèra absoliutus, vertinant gydymo veiksmingumą, ir dare prielaidą, jog tūriniai vertinimo kriterijai gali būti tikslesni [6]. Tyrimų duomenys ir mokslinèje literatūroje publikuojami tyrimų rezultatai patvirtina, jog VT pokyčių vertinimas yra jautresnis atsako vertinimo metodas, lyginant su IA matavimais [14-17].

Tyrimo imtis atitinka literatūroje pateikiamus sergančiụjų PV demografinius duomenis: amžiaus vidurkis siekia 60-70 metų, PV dažniau serga vyrai [18].

Tyrime nustatyta stipri koreliacija tarp IA ir VT $(\mathrm{r}=0,920)$, o ištirti dydžių skirtumai tarp rankinių ir pusiau automatinių matavimų nebuvo reikšmingi. Tai leidžia nustatytus IA ir VT dydžių pokyčius vertinti kaip patikimus.

Remiantis tyrimo duomenimis, VT vertinimas yra jautresnis metodas nustatyti PL bei DA nei IA ir VS matavimai (3 pav.). Gauti rezultatai atitinka Force J. ir bendraautorių pateiktą išvadą, kad tūrio matavimas yra jautresnis vertinant PL [16]. Remiantis gautais duomenimis, PL vertinant VT I ir II kontroliniuose tyrimuose nustatoma atitinkamai 13,8 proc. ir 6,9 proc. dažniau nei vertinant IA pokyti. Panašus 9 proc. PL neatitikimas nustatytas ir publikuotame kitu tyrejju darbe [16]. Šio tyrimo rezultatai patvirtina Force J. ir kitų autorių išvadas, jog atliekant VT matavimus PL nustatoma dažniau ir anksčiau nei taikant RECIST 1.1 kriterijus, todèl VT matavimas gali būti ypač svarbus, kai atsako vertinimas pagal RECIST 1.1 kelia abejonių, o nustatomi IA pokyčiu dydžiai yra ribiniai, nes tai gali sąlygoti optimalios gydymo taktikos parinkimą. Visa tai rodo šio tyrimo rezultatai. IA didejjimas, atitinkantis PL, nustatytas II kontroliniame tyrime siekè 35,9 proc. ir atitiko jau I kontroliniame tyrime pagal VT pokyčius nustatytą PL (36,6 proc.). Taigi, šiuo atveju klinikinėje praktikoje 52 iš 53 pacientų, vertinant naviko tūrio pokyti, PL galèjo būti nustatyta anksčiau.

Ankstyvas PL nustatymas chemoterapija gydomiems pacientams gali padèti išvengti reikšmingų hemopoezès sutrikimų, nefrotoksinio ir kitų šalutinių su chemoterapija siejamų poveikių [19]. Gydant taikinių terapija, 25 proc. atvejų formuojasi ertmès ir galimas navikinių masių augimas ertmės viduje (progresavimas iš vidaus). Šiais atvejais RECIST 1.1 klinikinis panaudojimas labai ribotas, atsakas gali būti ịvertinamas neteisingai (4 pav.).

Naviko tūrio vertinimas gali būti alternatyva linijiniams matavimams, tačiau reikalingi tolesni tyrimai, 


\section{Moksliniai darbai ir apžvalgos}

siekiant standartizuoti metodiką [20]. Tūrio matavimas pusiau automatiniu būdu neabejotinai paprastesnis ir greitesnis, lyginant su rankiniu metodu, tačiau dèl segmentacijos klaidų išmatuotos reikšmès skirtumai gali siekti 80 proc., o trečdaliu atveju tai sąlygoja klaidingą atsako vertinimą $[8,21]$. Svarbi tyrejo kompetencija atliekant segmentavimo korekcijas: įvertinti darinių ryši su bronchais, pleura arba kraujagyslemis, koreguoti darinio ribas [10]. Lubner MG. išskyrè trijų skirtingu kompetencijų vertintojus, kurių linijinių matavimų ir tūrių rezultatų pasiskirstymas tarp grupių (PL, DA, SL) skyrèsi apie 20 proc., o labiausiai skyrèsi tarp PL bei SL grupių [17]. Tyrimo duomenimis, reikšmingų skirtumų tarp rankinio ir pusiau automatinio matavimo nenustatyta.

Vertinant tūrị, gauti reikšmingi rezultatai, kai matuotas ir vertintas tikrasis - elipsès, o ne sferinis tūris. Panašius rezultatus gavo ir Hayes S. su bendraautoriais. Jie teigia, jog elipsès forma atitinka tikrąją naviko formą bei nustaté, kad elipsès VT vertinimas yra geresnis išgyvenamumo prognostinis rodiklis [7].

Tyrimo robotumas, kad šiame retrospektyviame tyrime neanalizuoti galimi atsako kategorinio vertinimo skirtumai pacientui, nevertinti matavimu skirtumai tarp tyrejjų, netirtas galimas ryšys su taikytu gydymu. Tyrime neanalizuota galima laiko intervalu tarp kontrolinių KT tyrimų ịtaka kategoriniam atsako ivertinimui.

\section{IŠVADOS}

Nustatytas labai stiprus ryšys tarp naviko ilgosios ašies ir tikrojo tūrio. Tikrojo naviko tūrio analizè yra jautresnis metodas vertinant atsaką $\mathfrak{i}$ gydymą ir nustatant progresuojančią ligą pacientams, kurie serga plaučių vèžiu.

Tikrojo naviko tūrio pokyti gali būti tikslinga vertinti šiais atvejais: kai ilgosios ašies padidejjimas nesiekia ribinès 20 proc. reikšmės; kai naviko ilgoji ašis dinamikoje mažai kinta, lyginant su trumpąja ašimi; kai navike yra ertmès.

Gauta 20200315

Priimta 20200417

\section{LITERATŨRA}

1. Blandin Knight S, Crosbie P, Balata H, Chudziak J, Hussell T, Dive C. Progress and prospects of early detection in lung cancer. Open Biol. 2017; 7(9). pii:170070.

2. Chen R, Tao Y, Xu X, Shan L, Jiang H, Yin Q, et al. The efficacy and safety of nivolumab, pembrolizumab, and atezolizumab in treatment of advanced non-small cell lung cancer. Discov Med. 2018; 26(143):155-66.

3. Barlesi F, Scherpereel A, Gorbunova V, Gervais R, Vikstrom A, Chouaid C, et al. Maintenance bevacizumab-pemetrexed after first-line cisplatin-pemetrexed-bevacizumab for advanced nonsquamous nonsmall-cell lung cancer: updated survival analysis of the AVAPERL (MO22089) randomized phase III trial. Ann Oncol. 2014; 25(5):1044-52.

4. Patel SA, Minn AJ. Combination Cancer Therapy with Immune Checkpoint Blockade: Mechanisms and Strategies. Immunity. 2018; 48(3):417-33.

5. Morgan RL, Camidge DR. Reviewing RECIST in the Era of Prolonged and Targeted Therapy. J Thorac Oncol. 2018; 13(2):154-64.

6. Eisenhauer E, Therasse P, Bogaerts J, Schwartz L, Sargent D, Ford R, et al. New response evaluation criteria in solid tumours: Revised RECIST guideline (version 1.1). Eur J Cancer. 2009; 45(2):228-47.

7. Hayes S, Pietanza M, O'Driscoll D, Zheng J, Moskowitz C, Kris M, et al. Comparison of CT volumetric measurement with RECIST response in patients with lung cancer. Eur J Radiol. 2016; 85(3):524-33.

8. Nishino M. Tumor Response Assessment for Precision Cancer Therapy: Response Evaluation Criteria in Solid Tumors and Beyond. Am Soc Clin Oncol Educ Book. 2018; 38:1019-29.

9. Ma Y, Wang Q, Dong $\mathbf{Q}$, Zhan $\mathbf{L}$, Zhang J. How to differentiate pseudoprogression from true progression in cancer patients treated with immunotherapy. Am J Cancer Res. 2019; 9(8):1546-53.

10. Nishino M, Hatabu H, Johnson BE, McLoud TC. State of the art: Response assessment in lung cancer in the era of genomic medicine. Radiology. 2014; 271(1):6-27.

11. Marom EM, Martinez CH, Truong MT, Lei X, Sabloff BS, Munden RF, et al. Tumor cavitation during therapy with antiangiogenesis agents in patients with lung cancer. J Thorac Oncol. 2008; 3(4):351-7.

12. Dinkel J, Khalilzadeh O, Hintze C, Fabel M, Puderbach $M$, Eichinger M, et al. Inter-observer reproducibility of semi-automatic tumor diameter measurement and volumetric analysis in patients with lung cancer. Lung Cancer. 2013; 82(1):76-82.

13. Therasse P, Arbuck SG, Eisenhauer EA, Wanders J, Kaplan RS, Rubinstein L, et al. New guidelines to evaluate the response to treatment in solid tumors. European Organization for Research and Treatment of Cancer, National Cancer Institute of the United States, National Cancer Institute of Canada. J Natl Cancer Inst. 2000; 92(3):205-16.

14. Gavrielides M, Kinnard L, Myers K, Petrick N. Noncalcified Lung Nodules: Volumetric Assessment with Thoracic CT. Radiology. 2009; 251(1):26-37.

15. Greenberg V, Lazarev I, Frank Y, Dudnik J, Ariad S, Shelef I. Semi-automatic volumetric measurement of response to chemotherapy in lung cancer patients: How wrong are we using RECIST? Lung Cancer. 2017; 108:90-5.

16. Force J, Rajan A, Dombi E, Steinberg SM, Giaccone G. Assessment of objective responses using volumetric evaluation in advanced thymic malignancies and metastatic non-small cell lung cancer. J Thorac Oncol. 2011; 6(7):1267-73.

17. Lubner MG, Stabo N, Lubner SJ, del Rio AM, Song C, Pickhardt PJ. Volumetric Versus Unidimensional Measures of Metastatic Colorectal Cancer in Assessing Disease Response. Clin Colorectal Cancer. 2017; 16(4):324-33.

18. Siegel R, Ma J, Zou Z, Jemal A. Cancer statistics, 2014. CA Cancer J Clin. 2014; 64(1):9-29.

19. Ardizzoni A, Boni L, Tiseo M, Fossella FV, Schiller JH, Paesmans M, et al. Cisplatin- versus carboplatin-based chemotherapy in first-line treatment of advanced non-small-cell lung cancer: an individual patient data meta-analysis. J Natl Cancer Inst. 2007; 99(11):847-57.

20. Crabb SJ, Patsios D, Sauerbrei E, Ellis PM, Arnold A, Goss G, et al. Tumor cavitation: impact on objective response evaluation in trials of angiogenesis inhibitors in non-small-cell lung cancer. J Clin Oncol. 2009; 27(3):404-10.

21. Gietema HA, Schaefer-Prokop CM, Mali WP, Groenewegen G, Prokop M. Pulmonary nodules: Interscan variability of semiautomated volume measurements with multisection CTinfluence of inspiration level, nodule size, and segmentation performance. Radiology. 2007; 245(3):888-94. 